O水津百合子, 松永 亨 (阪大), 森 望, 松永 喬 (奈良医大 ) 浅井英世, 大矢良人, 酒井国男 (関西労災病院)

(はじめに)

聴神経腫煌を含む小脳橋角部腫煌の診断における聴性脳幹反応 (ABR)の有用性については，今 までにも種々の報告がなされてきた。一方，後迷路性障害の際の蝸電図の所見についてもいくつ か報告はあるが, 同時に記録したものは外国, 本邦とも比較的少ない。我々は以前より ABRと蝸 電図を同時記録して聴神経腫瘍や小脳橋角部のその他の腫煬の診断に用いてきたが，今回はてれ らの所見を整理して, 両検査を併用するととの意義について検討してみた。又、聴神経腫煌の大 きさと健側の ABR 潜時との関係についても調べたので併せて報告する。

\title{
（対象および方法）
}

対象は阪大耳鼻科, 関西労災病院耳舅科わよび奈良医大耳鼻科を受診した患者で，CT-sean お よび手術によって睡煬の存在を確認されたものとし, そのうちわけは一側聴神経腫煌 20 例, 両側 聴神経腫瘍 2 例, 乙れ以外の小脑橋

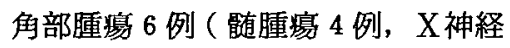
腫煌 1 例， V 神経腫煌 1 例)である。 検査方法は，ABRは前額部一耳垂 間誘導, 蝸電図は鼓室内および鼓室 外誘導法でおてなった。刺激音はク リック音を使用したが, 詳細は以前 亿報告した通りである12)。

\section{（結 果）}

$\mathrm{ABR}$ および蝸電図の APの結果は 表1,2 にまとめて示した。ABRにお ける後迷路性障害を示す所見として 表 1 聴柛経腫湯患者の ABR, AP 所見

(22名 24耳)

\begin{tabular}{|c|c|c|c|c|c|c|}
\hline \multirow{2}{*}{\multicolumn{2}{|c|}{$A$}} & \multicolumn{2}{|c|}{ 後迷路障害所見 (+) } & \multicolumn{2}{|c|}{ 後迷路挛害所見 (一) } & \multirow{3}{*}{$\frac{\text { 影 }}{2}$} \\
\hline & & \multirow[t]{2}{*}{$\begin{array}{c}\text { AP broad } \\
\text { wave }\end{array}$} & \multirow{2}{*}{\begin{tabular}{|c|}
$\begin{array}{l}\text { inappro } \\
\text { priate AP }\end{array}$ \\
I \\
\end{tabular}} & \multirow[t]{2}{*}{ 反応なし } & \multirow{2}{*}{$\frac{\text { その他 }}{1}$} & \\
\hline 後迷路 & $\begin{array}{l}\text { I 又心 } \\
\text { I, II のみ }\end{array}$ & & & & & \\
\hline$(+)$ & $I-V$ 延長 & & & & 6 & 6 \\
\hline \multirow{2}{*}{$\begin{array}{c}\text { 後迷路 } \\
\text { 陪害所見 } \\
(-)\end{array}$} & 反応なし & 1 & 2 & 9 & 1 & 13 \\
\hline & その他 & 1 & & & 2 & 3 \\
\hline \multicolumn{2}{|c|}{ 計 計 } & 2 & 3 & 9 & 10 & 24 \\
\hline
\end{tabular}

はI波のみ，ないしは I， II波のみ の波形, および $\mathrm{I}$ - V間隔の延長を とった。V波潜時の左右差について は後で述べる通り, 健側のV波潜時 も延長を示す例がかなり認められた 事と，患側V波の出現したものが少 なかったてとで, 今回は用いなかっ た。一方螎電図の APでは，AP broad wave, および inappropriate AP preservation を後迷路障害所見と考 えた3)4)。

聴神経腫煌群では後迷路性障害所 見の陽性率はABR 単独で $8 / 24,33$ $\%$ ，AP 単独のそれは $5 / 24 ， 21 \%$

表2 半の他の小脳橋角部腫瘍患者の ABR, AP 所見

(6名)

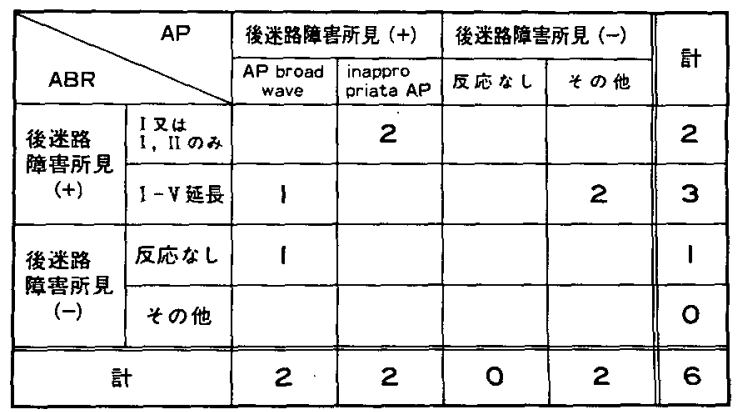


といずれも低いが， ABR・APを併用 し，いずれかで陽性所兒を示すもの とすると $12 / 24 ， 50 \%$ とやや上昇 する。特に ABRで no responseであっ た 13 例中の 4 例で, 蝸電図でAPが 䜑められたに注目される。

一方, 聴神経腫煌以外の小脳橋角 部腫煬例では, $\mathrm{ABR}$ のでの後迷路 性障害所見を示すものは $5 / 6,83 \%$ ， APのみで $4 / 6,67 \%$ ，両者あわせ ていずれか一方でも陽性のものは 6

\section{表 3 腫瘍の大きさと健側 ABR} （聴神経腫瘍）

\begin{tabular}{cccc}
\hline 腫瘍の大きさ (長径) & & $I-V$ 延長 & $I-V$ 正常 \\
\hline $1 \mathrm{~cm}$ 未満 & (2例) & 0 & 2 \\
$1 \mathrm{~cm}$ 以上 $2 \mathrm{~cm}$ 未満 & $(2$ 例 $)$ & 0 & 2 \\
$2 \mathrm{~cm}$ 以上 $3 \mathrm{~cm}$ 未満 & $(5$ 例 $)$ & 1 & 5 \\
$3 \mathrm{~cm}$ 以上 $4 \mathrm{~cm}$ 未満 & $(4$ 例 $)$ & 3 & 1 \\
$4 \mathrm{~cm}$ 以上 & $(2$ 例 $)$ & 2 & 0 \\
\hline
\end{tabular}

$/ 6,100 \%$ とった。

次に，聴神経腫瘍の患者のうち C T scan 亿て腫煌の大きさのわかったものについて，腫瘍の大 きさと健側 $\mathrm{ABR}$ 波形の I - V間隔の延長について調べてみた。表 3 に示す通り, 腫煌が $3 \mathrm{~cm}$ をて えると健側の $\mathrm{ABR} ， \mathrm{I}-\mathrm{V}$ 波間隔の延長を示す例が多い。更に詳細に検討すると，I - V 間隔の 延長しているものは全例とも - V間隔の延長によるものであった。

(考 按)

聴神経腫厦を含む小脳橋角部腫場の際の ABRの診断上の有用性については数多くの報告があり， 後迷路性障害の指標となるいくつかのパラメーターも示されている5567)。しかし，聴力障害の高度 な例, 特に聴神経腫痬では ABRの波形が出現せず診断上に役立ち得ない例も多い。今回, 我々は $\mathrm{ABR}$ とともに AP を併用するととで後迷路性障害の診断する上でより高い信頼性を得るてとが出 来た。特に聴神経腫瘃で $\mathrm{ABR}$ no responseの 13 例中 4 例で AP の波形を記録できた。聴神経腫 愓以外の小脳橋角部腫瘍では, 一般に ABRの有用性は高いが, 我々の例でも症例数は少ないがて の傾向は認められた。

次に，聴神経腫煌で腫煌の大きさと反対側 $\mathrm{ABR}$ の I - V間隔について比較してみると， $3 \mathrm{~cm}$ 上の腫㿟では，I - V 間隔，特にIII-V間隔の延長するものが多かった。従って反対側 $\mathrm{ABR}$ から ある程度, 腫煌の大きさが推定できると考えられる。

\section{（文 献）}

1) 森 望他；AP. BSR による内耳性障害と後迷路性障害の鑑別. Audiology(Japan)21；333-334, 1978.

2）森 望他；誘導法によるAPの差異について. Audiology $\left(\mathrm{J}_{\mathrm{apan}}\right) 23 ; 451$-452, 1980.

3) Gibson, W. P. R. et al. ; Electrocochleography in the diagnosis of acoustic neuroma. J. Laryngol Otol. $90 ; 127-139,1976$.

4) Coats. A.C. ; Human auditory nerve action potential and brain stem evoked responses. Arch otolaryngol, $104 ; 709-717,1978$.

5) Clems. J.D. et al. ; Brain stem electric response audiometry in the differential diagnosis of acoustic tumors. ; Laryngoscope 89;31-42, 1979.

6) Terkildsen. K. et al. ; Auditory brain stem responses in the diagnosis of cerebellopontine angle tumors. Scand. Audiol. 6 ; $43-47,1977$.

7) Selters. W. A. et al. ; Acoustic tumor detection with brain stem electric response audiometry. Arch. otolaryngol. 103;181-187, 1977 . 